\title{
PMEL Positive
}

National Cancer Institute

\section{Source}

National Cancer Institute. PMEL Positive. NCI Thesaurus. Code C153405.

An indication that expression of PMEL has been detected in a sample. 